\title{
Ikaite crystal distribution in winter sea ice and implications for $\mathrm{CO}_{2}$ system dynamics
}

\author{
S. Rysgaard ${ }^{1,2,3,4}$, D. H. Søgaard ${ }^{3,6}$, M. Cooper ${ }^{2}$, M. Pućko ${ }^{1}$, K. Lennert ${ }^{3}$, T. N. Papakyriakou ${ }^{1}$, F. Wang ${ }^{1,5}$,

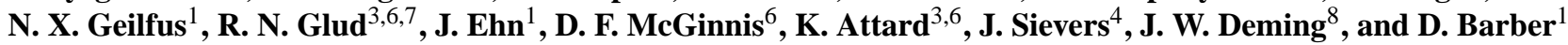 \\ ${ }^{1}$ Centre for Earth Observation Science, Department of Environment and Geography, University of Manitoba, Winnipeg, \\ MB R3T 2N2, Canada \\ ${ }^{2}$ Department of Geological Sciences, University of Manitoba, Winnipeg, MB R3T 2N2, Canada \\ ${ }^{3}$ Greenland Climate Research Centre, Greenland Institute of Natural Resources, 3900 Nuuk, Greenland \\ ${ }^{4}$ Arctic Research Centre, Aarhus University, 8000 Aarhus, Denmark \\ ${ }^{5}$ Department of Chemistry, University of Manitoba, Winnipeg, MB R3T 2N2, Canada \\ ${ }^{6}$ University of Southern Denmark and NordCEE, Odense M, Denmark \\ ${ }^{7}$ Scottish Association for Marine Science, Oban, UK \\ ${ }^{8}$ University of Washington, School of Oceanography, Seattle, WA, USA
}

Correspondence to: S. Rysgaard (soeren.rysgaard@ad.umanitoba.ca)

Received: 18 November 2012 - Published in The Cryosphere Discuss.: 6 December 2012

Revised: 30 March 2013 - Accepted: 2 April 2013 - Published: 23 April 2013

\begin{abstract}
The precipitation of ikaite $\left(\mathrm{CaCO}_{3} \cdot 6 \mathrm{H}_{2} \mathrm{O}\right)$ in polar sea ice is critical to the efficiency of the sea ice-driven carbon pump and potentially important to the global carbon cycle, yet the spatial and temporal occurrence of ikaite within the ice is poorly known. We report unique observations of ikaite in unmelted ice and vertical profiles of ikaite abundance and concentration in sea ice for the crucial season of winter. Ice was examined from two locations: a $1 \mathrm{~m}$ thick land-fast ice site and a $0.3 \mathrm{~m}$ thick polynya site, both in the Young Sound area $\left(74^{\circ} \mathrm{N}, 20^{\circ} \mathrm{W}\right)$ of NE Greenland. Ikaite crystals, ranging in size from a few $\mu \mathrm{m}$ to $700 \mu \mathrm{m}$, were observed to concentrate in the interstices between the ice platelets in both granular and columnar sea ice. In vertical sea ice profiles from both locations, ikaite concentration determined from image analysis, decreased with depth from surface-ice values of $700-900 \mu \mathrm{mol} \mathrm{kg}^{-1}$ ice $\left(\sim 25 \times 10^{6}\right.$ crystals kg-1$)$ to values of $100-200 \mathrm{~mol} \mathrm{~kg}^{-1}$ ice $\left(1-7 \times 10^{6}\right.$ crystals kg-1) near the sea ice-water interface, all of which are much higher (410 times) than those reported in the few previous studies. Direct measurements of total alkalinity (TA) in surface layers fell within the same range as ikaite concentration, whereas TA concentrations in the lower half of the sea ice were twice as high. This depth-related discrepancy suggests interior ice processes where ikaite crystals form in surface sea ice layers
\end{abstract}

and partly dissolve in layers below. Melting of sea ice and dissolution of observed concentrations of ikaite would result in meltwater with a $p \mathrm{CO}_{2}$ of $<15 \mu \mathrm{atm}$. This value is far below atmospheric values of $390 \mu \mathrm{atm}$ and surface water concentrations of $315 \mu \mathrm{atm}$. Hence, the meltwater increases the potential for seawater uptake of $\mathrm{CO}_{2}$.

\section{Introduction}

As sea ice forms from seawater, dissolved salts are trapped in interstitial liquid brine inclusions. Because phase equilibrium must be maintained between these inclusions and the surrounding ice, the brine becomes increasingly concentrated as temperatures decrease. Solid salts begin to precipitate out of solution, starting with ikaite $\left(\mathrm{CaCO}_{3} \cdot 6 \mathrm{H}_{2} \mathrm{O}\right)$ at $-2.2^{\circ} \mathrm{C}$, mirabilite $\left(\mathrm{NaSO}_{4} \cdot 10 \mathrm{H}_{2} \mathrm{O}\right)$ at $-8.2{ }^{\circ} \mathrm{C}$ and hydrohalite $\left(\mathrm{NaCl} \cdot 2 \mathrm{H}_{2} \mathrm{O}\right)$ at $-23^{\circ} \mathrm{C}$ (Assur, 1960). The mineral ikaite was recently discovered in springtime sea ice in both hemispheres (Dieckmann et al., 2008, 2010). Ikaite crystals appeared to be present throughout the sea ice, but with larger crystals and higher abundance in surface layers (Dieckmann et al., 2010; Rysgaard et al., 2012; Geilfus et al., 2013). Ikaite crystals of various sizes and morphologies have been isolated 
from sea ice. They range in size from a few $\mu \mathrm{m}$ to large $\mathrm{mm}$ size crystals; all are highly transparent with rounded rhombic morphology and show uniform extinction under crossed polarized light, suggesting simple, single well-crystalline crystals. The specific conditions promoting ikaite precipitation in sea ice are poorly understood, but if precipitation occurs during the ice-growing season in the porous lower sea ice layer, where the brine volume is greater than $5 \%$ (Weeks and Ackley, 1986; Golden et al., 1998, 2007; Ehn et al., 2007), then the resulting $\mathrm{CO}_{2}$-enriched brine will exchange with seawater via gravity drainage (Notz and Worster, 2009). Earlier work has led to the suggestion that ikaite crystals may remain trapped within the skeletal layer where they act as a store of TA, becoming a source of excess TA to the ocean water upon subsequent mineral dissolution during summer melt (Nedashkovsky et al., 2009; Rysgaard et al., 2011). This excess would lower the partial pressure of $\mathrm{CO}_{2}\left(p \mathrm{CO}_{2}\right)$ of surface waters affected by melting sea ice and cause an increase in the air-sea $\mathrm{CO}_{2}$ flux.

At this point, the spatial and temporal occurrence of ikaite precipitates within sea ice is poorly constrained. There is urgency for increasing the knowledge base, given that the precipitation of $\mathrm{CaCO}_{3}$ is implicated in many processes of global significance, including the sea ice-driven carbon pump and global carbon cycle (Delille et al., 2007; Rysgaard et al., 2007, 2011; Papadimitriou et al., 2012) and pH conditions (acidification) in surface waters (Rysgaard et al., 2012; Hare et al., 2013). Quantification of $\mathrm{CaCO}_{3}$ crystals in sea ice in the few previous studies has been made on melted samples assuming that ikaite will not dissolve if temperature is maintained below $4{ }^{\circ} \mathrm{C}$. In principle, however, dissolution may also be related to the reaction of ikaite with $\mathrm{CO}_{2}$ in the meltwater or with the atmosphere during the melting procedure, which can last for days at low temperature allowing the possibility of changing $\mathrm{pH}$ in the surroundings of the ikaite crystal and underestimation of ikaite concentration. Examining ikaite in such melted samples also makes it impossible to evaluate spatial distribution within the sea ice matrix on the micrometer to millimeter scale and determine whether or not the mineral is entrapped in the ice crystal lattice and thus separated from the solution.

Precipitation of ikaite in standard seawater conditions is described by

$\mathrm{Ca}^{2+}+2 \mathrm{HCO}_{3}^{-}+5 \mathrm{H}_{2} \mathrm{O} \leftrightarrow \mathrm{CaCO}_{3} \cdot 6 \mathrm{H}_{2} \mathrm{O}+\mathrm{CO}_{2}$.

Brine drainage from sea ice is expected to result in a removal of dissolved $\mathrm{CO}_{2}$ along with salts. If precipitated ikaite crystals become trapped within sea ice interstices, then the reaction in Eq. (1) is pushed to the right in brine, providing further potential for $\mathrm{CaCO}_{3}$ growth. Over time, the concentration of trapped ikaite crystals could increase. Here we provide novel tests of these ideas during crucial winter conditions by examining ikaite in intact (unmelted) natural sea ice and determining detailed vertical ikaite distributions in the sea ice from two locations in Young Sound (northeast
Greenland). Combined with other measurements and model calculations, the results allow us to relate sea ice formation and melt to the observed $p \mathrm{CO}_{2}$ conditions in surface waters, and hence, the air-sea $\mathrm{CO}_{2}$ flux.

\section{Methods}

\subsection{Study site and sampling}

Sampling was performed at two locations in the Young Sound area $\left(74^{\circ} \mathrm{N}, 20^{\circ} \mathrm{W}\right.$ : Rysgaard and Glud, 2007), NE Greenland, in March 2012 (Fig. 1). The land-fast ice station, ICE I $\left(74^{\circ} 18.5764^{\prime} \mathrm{N}, 20^{\circ} 18.2749^{\prime} \mathrm{W}\right)$, was in the fjord with $110-115 \mathrm{~cm}$ thick sea ice covered by $70 \mathrm{~cm}$ of snow. Freeboard at ICE I was negative, e.g. when a hole was drilled through the ice, the ice surface flooded. However, at sites without drilled holes, we did not observe flooding during our experiment and there was a distinct snow-ice interface. On top of the ice of ICE I, about $8 \mathrm{~cm}$ of slush snow at the snowice interface was observed. The new-ice station, POLY I $\left(74^{\circ} 13.905^{\prime} \mathrm{N}, 20^{\circ} 07.701^{\prime} \mathrm{W}\right)$, was situated in a polynya region about $3 \mathrm{~km}$ off the sharp land-fast ice edge, where sea ice regularly breaks up in winter. At the time of sampling, POLY I was $15-30 \mathrm{~cm}$ thick and covered by $17 \mathrm{~cm}$ of snow. At POLY I there was negative freeboard too - with about $2 \mathrm{~cm}$ of slush snow at the snow-ice interface. At POLY I the snow was denser up to $\sim 8 \mathrm{~cm}$ from the ice interface, then a bit lighter (newer snow) above. Air temperature during sampling ranged from -20 to $-25^{\circ} \mathrm{C}$. The polynya site is representative of thin Arctic sea ice, whereas the ICE I location is representative of fjord ice in the Arctic where there is a large source of winter precipitation (snow). Snow was very dry and very cold (unlike Antarctic ice). There was also no surface flooding. ICE I is typical of sea ice in fjords or where large moisture sources are available to the Arctic winter climate system.

Sea ice cores were extracted using a MARK II coring system (Kovacs Enterprises). Vertical temperature profiles were measured with a thermometer (Testo Orion 3-star with an Orion $013610 \mathrm{MD}$ conductivity cell) in the center of the cores immediately after coring. Sea ice was then cut into 5-10 cm sections, kept cold and brought to the field laboratory within $1 \mathrm{~h}$ for processing. In the $20^{\circ} \mathrm{C}$ laboratory, sea ice sections were melted for measurement of bulk salinity with a conductivity probe (Thermo Orion 3-star with an Orion $013610 \mathrm{MD}$ conductivity cell, UK) calibrated against a $15 \mathrm{~N}$ $\mathrm{KCL}$ solution at $20^{\circ} \mathrm{C}$. Brine volume in sea ice was calculated according to Cox and Weeks (1983) and Leppäranta and Manninen (1988). Brine salinity was calculated from the measured sea ice temperatures and freezing point of seawater (Unesco, 1978).

Although there was a lot of snow on the thick fast ice in the fjord there was not natural flooding of the surface. When we installed ocean instruments (drilling through the ice) we 


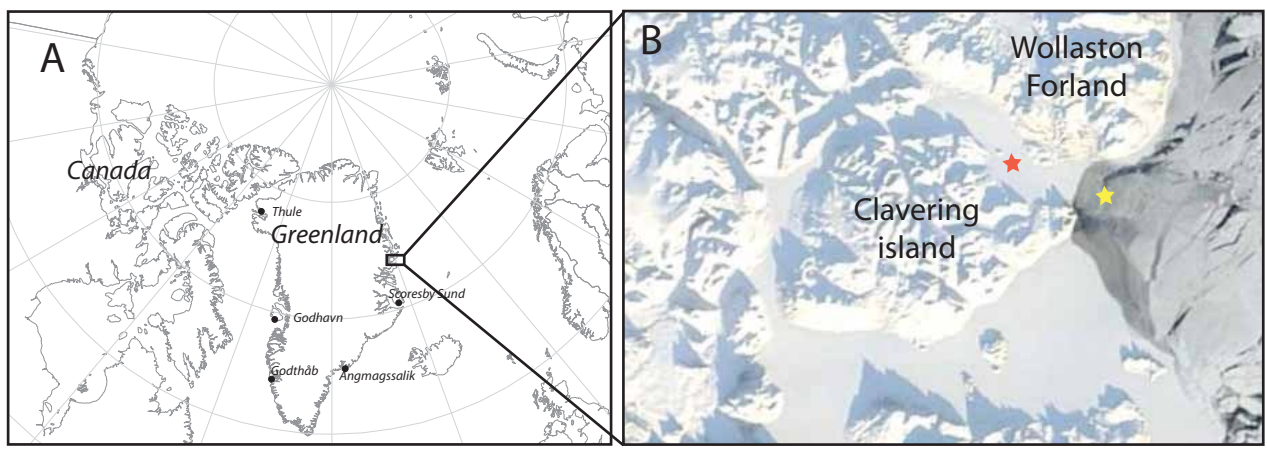

Fig. 1. Study site. (A) Greenland showing the study area (box) and (B) the Young Sound fjord between Wollaston Forland and Clavering Island. Sea ice coring sites for the land-fast ice location (ICE I) is shown as a red star and the polynya coring site (POLY I) as a yellow star. The satellite image showing land-fast ice in the fjord and thin ice-open water conditions in the polynya outside the fjord is from early March 2012.

created some artificial flooding. A widely distributed snowice interface survey, however, showed that flooding was limited to only the area immediately surrounding the installed instruments. The same was the case for the Polynya site.

\subsection{Analysis}

In the cold laboratory $\left(-20\right.$ to $\left.-25^{\circ} \mathrm{C}\right)$, corresponding sea ice cores were cut into vertical thick sections $(10 \mathrm{~cm} \times 6 \mathrm{~cm} \times 1 \mathrm{~cm})$ and horizontal thick sections $(6 \mathrm{~cm} \times 6 \mathrm{~cm} \times 1 \mathrm{~cm})$, then mounted onto slightly warmed glass plates and thinned to $1-3 \mathrm{~mm}$ thickness using a microtome (Leica SM 2010R). Each section was then photographed (Nikon D70) using polarized filters to document ice texture. Subsequently, each thin section was inspected under a stereomicroscope (Leica M125 equipped with a Leica DFC 295 camera and Leica Application Suite ver. 4.0.0. software) to document the vertical and horizontal position of ikaite crystals in sea ice.

To document the abundance and concentrations of ikaite crystals in sea ice, $20-90 \mathrm{mg}$ of sea ice were cut off, using a stainless steel knife, at three random places within each 5$10 \mathrm{~cm}$ sea ice section. These subsamples were weighed and placed onto a glass slide that rested on a chilled aluminum block with a $1 \mathrm{~cm}$ central viewing hole, then brought into the $20^{\circ} \mathrm{C}$ laboratory. There they were inspected intact under a microscope (Leica DMiL LED) under 100-400 magnification as they were also allowed to melt. A few seconds after the sea ice had melted the first image was taken (same camera and software as described above). This image was used to document the amount and concentration of ikaite crystals (further details given below). After 2-5 min the second image was taken and compared with the first one. If crystals were dissolving, they were assumed to be ikaite. Three random samples, each covering $1.07 \mathrm{~mm}^{2}$ of the counting area, were imaged in this fashion. The area of the melted sea ice sample was determined after thawing to calculate the counted area to total area ratio. Ikaite crystals and other precipitates were observed to settle to the glass slide rapidly after ice crystal melt due to their high density. In total, three $20-90 \mathrm{mg}$ sea ice sub-samples were processed from each sea ice section in triplicates, resulting in 9 replicate images for each $5-10 \mathrm{~cm}$ vertical sea ice section.

The abundance and concentrations of crystals were calculated from the images using the software ImageJ $(1.45 \mathrm{~s})$. Individual images were brightness/contrast adjusted prior to binary file conversion. A "close-function" routine then ensured that crystals were closed before "filling-holes" with black. An "analyze" routine was then applied to count the crystals and analyze their area relative to counting area. This ratio was multiplied by the area of the melted ice subsample. For concentration estimates of ikaite a cubic form was assumed for the mineral. Ikaite concentration in sea ice was calculated from its volume, density $\left(1.78 \mathrm{~g} \mathrm{~cm}^{-3}\right)$, molar weight $\left(208.18 \mathrm{~g} \mathrm{~mol}^{-1}\right)$, and weight of subsample and converted into $\mu \mathrm{mol} \mathrm{kg}{ }^{-1}$ melted sea ice units.

A sea ice core (entire core) from each site was kept at $-20^{\circ} \mathrm{C}$ for three weeks and brought to the x-ray laboratory at the Department of Geological Sciences at the University of Manitoba, Canada. There, $20-90 \mathrm{mg}$ subsamples of sea ice were cut randomly from each sea ice section (5$10 \mathrm{~cm}$ vertical sections) and mounted onto a cold glass slide resting on a chilled aluminum block containing a $1 \mathrm{~cm}$ central viewing hole. The crystals were first examined with a polarized light microscope to assess their optical properties and then mounted for x-ray study using a stereo binocular microscope. Ikaite crystals were selected from each $10 \mathrm{~cm}$ section of the sea ice cores from both ICE I and POLY I, dragged across the cold glass slide using a metal probe and immersed into a drop of special purpose sampling oil that restricted sublimation. Each crystal was then scooped up with a low x-ray scattering micro-loop and instantly transferred to the nitrogen cold stream $\left(-10^{\circ} \mathrm{C}\right)$ on the $\mathrm{x}$-ray diffraction instrument with a magnetic coupling goniometer head. The 
x-ray diffraction instrument consisted of a Bruker D8 threecircle diffractometer equipped with a rotating anode generator (MoK $\alpha$ X-radiation), multi-layer optics, APEX-II CCD detector, and an Oxford 700 Series liquid-N Cryostream. The intensities of more than 100 reflections were harvested from six frame series (each spanning $15^{\circ}$ in either $\omega$ or $\varphi$ ) collected to $60^{\circ} 2 \theta$ using $0.6 \mathrm{~s}$ per $1^{\circ}$ frame with a crystalto-detector distance of $5 \mathrm{~cm}$. In total, 12 crystals (one from all ice layers investigated from both ICE I and POLY I) were identified through successful indexing of observed $\mathrm{x}$ ray diffraction maxima onto known characteristic unit cells.

To determine TA and total dissolved inorganic carbon $\left(T \mathrm{CO}_{2}\right)$ concentrations in sea ice, three sea ice cores were cut into $5-10 \mathrm{~cm}$ sections and brought to the field laboratory. Here, the ice segment was placed immediately in a gas-tight laminated (Nylon, ethylene vinyl alcohol, and polyethylene) plastic bag (Hansen et al., 2000) fitted with a $50 \mathrm{~cm}$ gastight Tygon tube and a valve for sampling. The weight of the bag containing the sea ice sample was recorded. Cold $\left(1{ }^{\circ} \mathrm{C}\right)$ deionized water $(25-50 \mathrm{~mL})$ of known weight and TA and $T \mathrm{CO}_{2}$ concentration was added. The plastic bag was closed immediately and excess air and deionized water quickly removed through the valve and weighed. The weight of the deionized water accounted for $<5 \%$ of the sea ice weight. This processed sea ice was subsequently melted, and the meltwater mixture transferred to a gas-tight vial $(12 \mathrm{ml} \mathrm{Ex-}$ etainer, Labco High Wycombe, UK). Any $\mathrm{CaCO}_{3}$ crystals present in these ice core sections are expected to have dissolved during sample processing and, thus, be included in the measured TA and $T \mathrm{CO}_{2}$ concentrations. Standard methods of analysis were used: $T \mathrm{CO}_{2}$ concentrations were measured on a coulometer (Johnson et al., 1987), TA by potentiometric titration (Haraldsson et al., 1997), and gaseous $\mathrm{CO}_{2}$ by gas chromatography. Routine analysis of Certified Reference Materials (provided by A. G. Dickson, Scripps Institution of Oceanography) verified that $T \mathrm{CO}_{2}$ and TA concentrations ( $n=3$ ) could be analyzed within $\pm 1 \mu \mathrm{mol} \mathrm{kg}{ }^{-1}$ and $\pm 4 \mu \mathrm{mol} \mathrm{kg}{ }^{-1}$, respectively. Bulk concentrations of TA and $T \mathrm{CO}_{2}$ in the sea ice $\left(C_{i}\right)$ were calculated as $C_{i}=\left(\left[C_{\mathrm{m}} W_{\mathrm{m}}-\right.\right.$ $\left.\left.C_{\mathrm{a}} W_{\mathrm{a}}\right] / W_{\mathrm{i}}\right)$, where $C_{\mathrm{m}}$ is the TA or $T \mathrm{CO}_{2}$ concentration in the meltwater mixture, $W_{\mathrm{m}}$ is the weight of the meltwater mixture, $C_{\mathrm{a}}$ is the TA or $T \mathrm{CO}_{2}$ concentration in the deionized water, $W_{\mathrm{a}}$ is the weight of the deionized water, and $W_{\mathrm{i}}$ is the weight of the sea ice (Rysgaard et al., 2008).

Following the bulk determination of $T \mathrm{CO}_{2}$ and TA, the bulk $p \mathrm{CO}_{2}$ and $\mathrm{pH}$ (on the total scale) were computed using the temperature and salinity conditions in the field and a standard set of carbonate system equations, excluding nutrients, with the CO2SYS program of Lewis and Wallace (2012). We used the equilibrium constants of Mehrbach et al. (1973) refitted by Dickson and Millero (1987, 1989).

In summary, triplicate cores were collected 18, 20 and 24 March for snow and ice thickness determination, ice temperatures and bulk ice salt concentrations. Measurements were performed on the same cores. Triplicate separate cores were sampled for determination of $T \mathrm{CO}_{2}$ and TA concentrations. Ice texture, density and photo documentation of ikaite location in intact ice corers were performed on triplicate separate cores (ICE I, 17 March: POLY I, 20 March). Ikaite image analysis for concentration determination was done on three separate cores collected 18, 20 and 24 March. X-ray diffraction analyses were performed on a separate core collected 24 March. Samples for bulk salt, TA, $T \mathrm{CO}_{2}$, ikaite crystal abundance and concentration were processed immediately in the field laboratory. Crystals for ikaite determination on $\mathrm{x}$-ray were kept frozen $\left(-20^{\circ} \mathrm{C}\right)$ until analysis a month later. Photo documentation showed that ikaite crystal morphology did not change due to storage. Thus, prolonged freezing period prior analysis should not affect the results obtained. However, it is important that preservation of TA, $T \mathrm{CO}_{2}$ and quantification of ikaite is done in the field. These samples should not be stored at low temperatures before analysis as $\mathrm{CaCO}_{3}$ could be produced during the storage.

\subsection{FREZCHEM modeling}

The production of ikaite in the sea ice cores was modeled by FREZCHEM (version 10), an equilibrium chemical thermodynamic model parameterized for concentrated solutions (up to $20 \mathrm{~mol} \mathrm{~kg}^{-1}\left(\mathrm{H}_{2} \mathrm{O}\right)$ ) and sub-zero temperatures (to $-70^{\circ} \mathrm{C}$ ) (Marion et al., 2010). The model uses the Pitzer approach correcting for activity coefficients of solutes in concentrated solutions. Our calculation was done by following the freezing process of seawater with the same chemical composition as the local seawater under the local $p \mathrm{CO}_{2}$ values; the thermodynamic constants used were the default values provided with the model. It should be noted that FREZCHEM modeling is based on the assumption that chemical species in the sea ice environment (ice, brine, and air) have reached thermodynamic equilibrium, and that most of the thermodynamic constants used in the model were extrapolated to low temperatures rather than being directly determined experimentally. Nevertheless, the model has shown promising applications in exploring cold geochemical processes associated with seawater freezing among many others (Marion et al., 1999, 2010).

\section{Results}

Sea ice covered the fjord on our arrival, but there was a polynya outside the fjord with a distinct ice edge running across the fjord between Wollaston Forland and Clavering Island (Fig. 1). Several freezing and opening incidents were observed in this area from satellite images prior to our arrival; however, due to low temperatures of $-20^{\circ} \mathrm{C}$ to $-36^{\circ} \mathrm{C}$ and calm conditions, the polynya began to re-freeze prior to our sampling. Due to the insulating effect of the thick $(70 \mathrm{~cm})$ snow cover at ICE I, our land-fast station in the fjord, sea ice surface temperature was relatively warm, $-10^{\circ} \mathrm{C}$, 

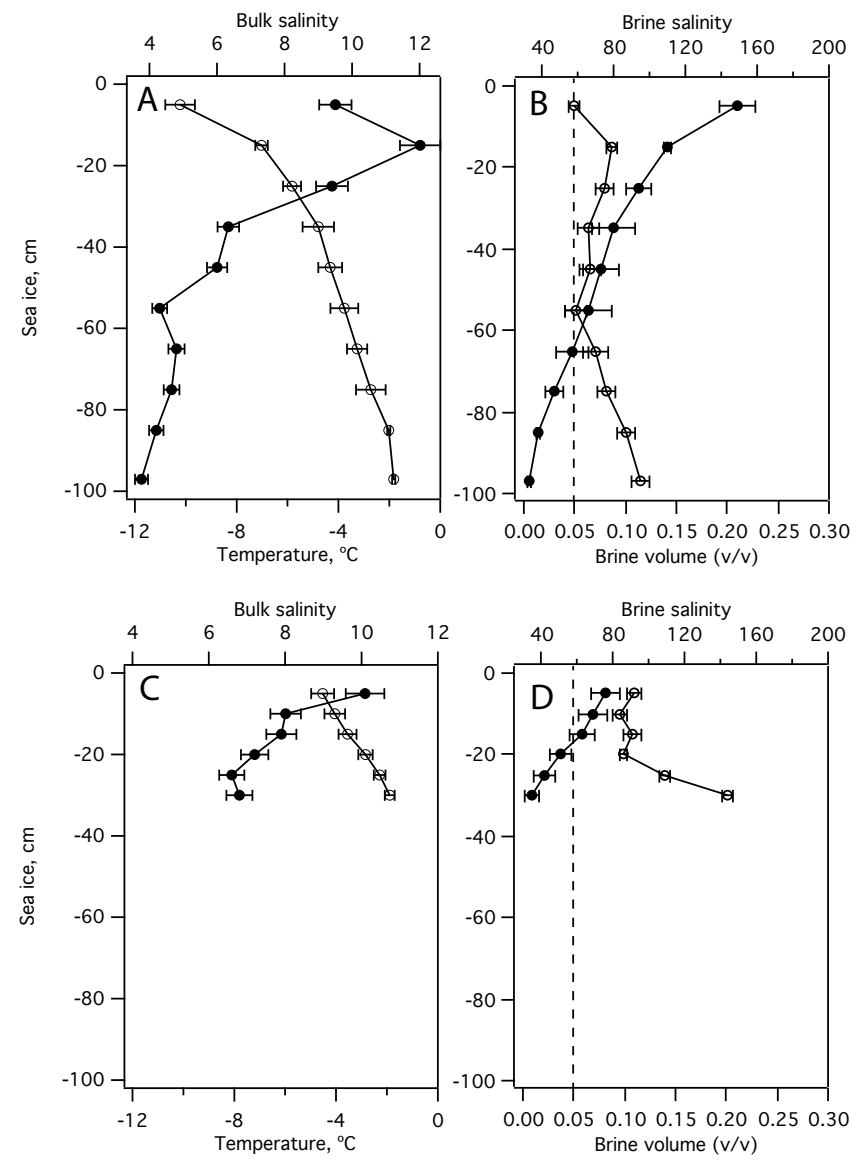

Fig. 2. Vertical profiles of sea ice features. (A) Temperature (-o-) and bulk salinity (- $\bullet-)$ and (B) brine volume (-o-) and brine salin-

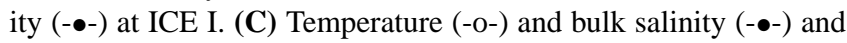
(D) brine volume (-o-) and brine salinity (-๑-) at POLY I. Vertical dotted line represents the brine volume where sea ice becomes permeable.

with a gradient to $-2{ }^{\circ} \mathrm{C}$ towards the sea ice-water interface (Fig. 2a). Bulk salinities ranged from 10-12 in the top layers to 4 at the bottom. Calculated brine volumes ranged from less that $5 \%$ in surface layers to $12 \%$ near the bottom (Fig. 2b); brine salinities, from 150 in the surface sea ice to 33 near the water column. At POLY I, our new-ice station in the polynya where snow cover was thinner $(17 \mathrm{~cm})$, surface sea ice temperature was only $-5^{\circ} \mathrm{C}$ (Fig. 2c) due to the rapid freezing with concurrent heat release and proximity to the water column (thin ice of $15-30 \mathrm{~cm}$ ). Bulk salinities ranged from 10 in surface ice layers to 7 in the lower ice layers (Fig. 2c). Given high bulk salinities and temperatures, brine volumes ranged from $10 \%$ in the top layers to $20 \%$ in the lower ice layers; brine salinities were lower at ICE I, ranging from 78 at the surface to 33 near the water column (Fig. 2d).

The upper $35 \mathrm{~cm}$ of sea ice at ICE I was composed of polygonal granular ice, formed through perculation and refreezing of brine and seawater into snow, i.e. snow ice (Fig. 3a). The snow ice formation was likely promoted by negative freeboard. The fact that we do not observe flooding is probably due to low temperatures (brine or seawater quickly refreezes in the cold snow). Daily images with automatic camera systems (MarinBasis Program, c/o Greenland Institute of Natural Resources) show that sea ice started to form locally outside the fjord in early October, and that those ice floes drifted into the fjord and consolidated with local ice to form a uniform ice cover that persisted through our study. Thus, the top layers of ice at ICE I may have been produced outside the fjord. The ice layer from $35-112 \mathrm{~cm}$ consisted of columnar sea ice (Fig. 3d). Microscopic examination of different vertical and horizontal ice thin sections showed the presence of ikaite crystals throughout the ice column (Fig. 3b, c and e, f). Ikaite crystals were located in the interstices between the ice platelets.

The sea ice at POLY I was less than one week old when first sampled. The upper $5 \mathrm{~cm}$ of the ice consisted of orbicular granular ice crystals, followed by transitional granular/columnar texture from 5 to $12 \mathrm{~cm}$ (Fig. 4a). This uppermost layer closely resembles the disc-like granular ice observed in nilas (Ehn et al., 2007) and may be related to freezing of brine expulsed to the sea ice surface. The transition into mainly columnar-like sea ice occurred at around 10 $12 \mathrm{~cm}$ from the surface and continued to the sea ice-water interface $(29 \mathrm{~cm})$; however, the disorderly structure implies intrusion of frazil ice and platelet ice forms, and thus supercooling at the ice-ocean interface was a significant factor in determining the ice structure. Similarly to ICE I, microscopic examination of thin ice sections from POLY I revealed the presence of ikaite crystals throughout the ice column (Fig. 4b, c and e, f). Ikaite crystals were again observed primarily in the interstices between the ice platelets.

Ikaite crystals become easily visible when the sea ice melts. As an example from POLY 1, 19 crystals were observed a few seconds after melting $50 \mathrm{mg}$ of randomly subsampled sea ice $(10-20 \mathrm{~cm}$ section; Fig. $5 \mathrm{a}$ and b). Allowing the crystals to dissolve for a few minutes before taking another image allowed us to identify ikaite crystals (as the ones that had dissolved; Fig. 5c). In this case, the crystal area covered $0.48 \%$ of the counting area.

At ICE I, the number of ikaite crystal per $\mathrm{kg}$ of melted ice ranged from $\sim 25 \times 10^{6} \mathrm{~kg}^{-1}$ in the upper layers to $\sim 1 \times 10^{6} \mathrm{~kg}^{-1}$ near the ice-water interface (Fig. 6a). At POLY I, similar ikaite abundances were observed in upper ice layers, whereas abundances near the water column reached $\sim 7 \times 10^{6} \mathrm{~kg}^{-1}$ (Fig. 6b). The molar concentration of ikaite per kg melted ice at ICE I decreased with depth from surface values of $900 \mu \mathrm{mol} \mathrm{kg}^{-1}$ to $100 \mu \mathrm{mol} \mathrm{kg}^{-1}$ near the ice-water interface. At POLY I, the highest concentrations $\left(700 \mu \mathrm{mol} \mathrm{kg}{ }^{-1}\right)$ were observed at $5-10 \mathrm{~cm}$ from the ice surface, decreasing to $\sim 200 \mu \mathrm{mol} \mathrm{kg}{ }^{-1}$ near the water column.

The crystals (a few $\mu \mathrm{m}$ to $700 \mu \mathrm{m}$ in size) observed in the sea ice were highly transparent with a rhombic morphology and showed uniform extinction under cross-polarized 

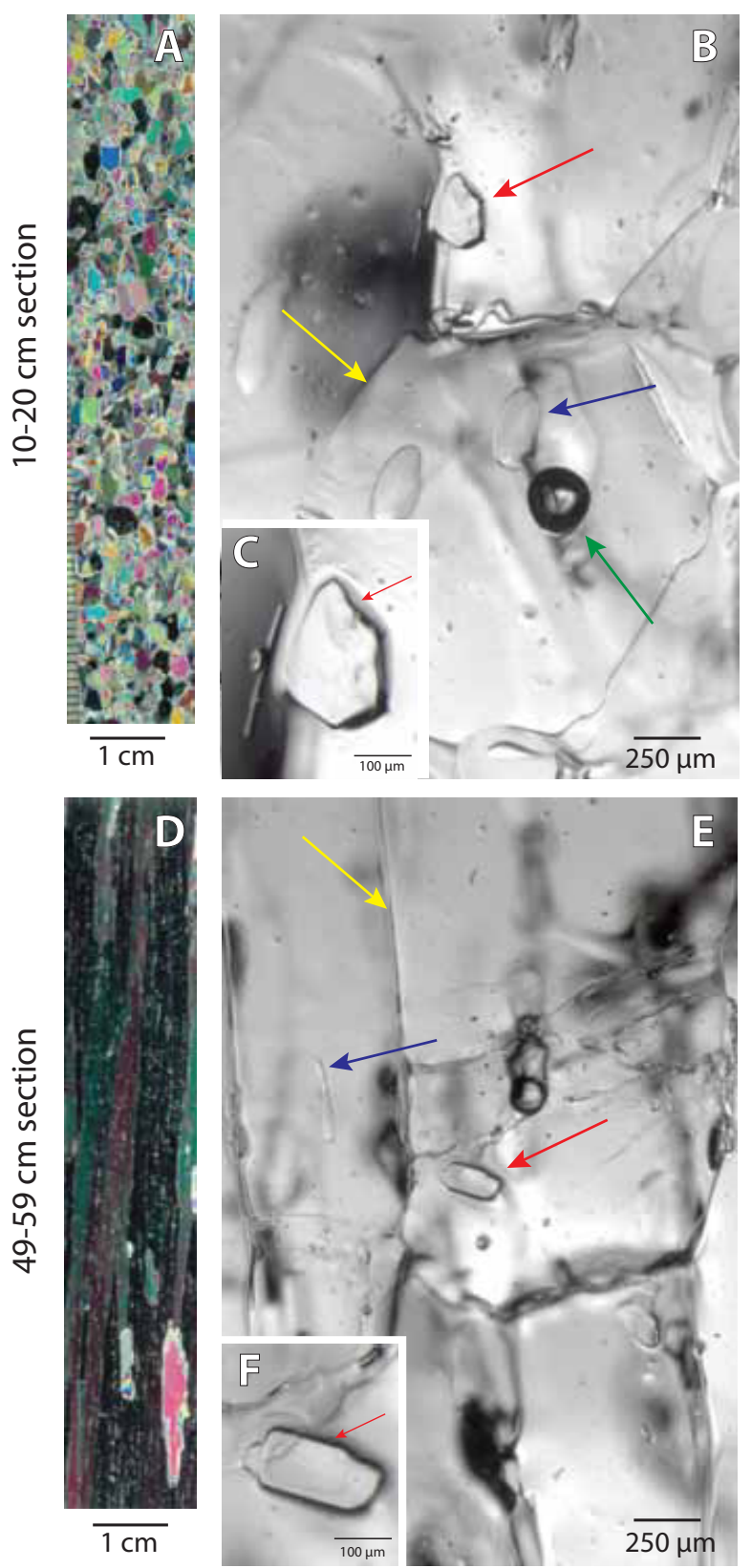

Fig. 3. Images of sea ice with ikaite crystals, from ICE I. (A, D) Sea ice texture (polarized light); (B, E) microscopic images of sea ice. Yellow arrows point to ice crystal borders, blue arrows to brine pockets, green arrows to air bubbles and red arrows to ikaite crystals. (C, F) Ikaite crystals at higher magnification. (A), (B) and (C) from 10-20 cm section; (D), (E) and (F) from $49-59 \mathrm{~cm}$ section.

light, suggesting that they were simple single crystals. All $\mathrm{x}$-ray reflections fitted well to a monoclinic $\mathrm{C}$-centered cell with refined cell parameters shown in Table 1. From the general shape, optical properties and unit-cell determination, the crystals examined were ikaite (Hesse and Küppers, 1983). The crystals identified as ikaite had a very distinct
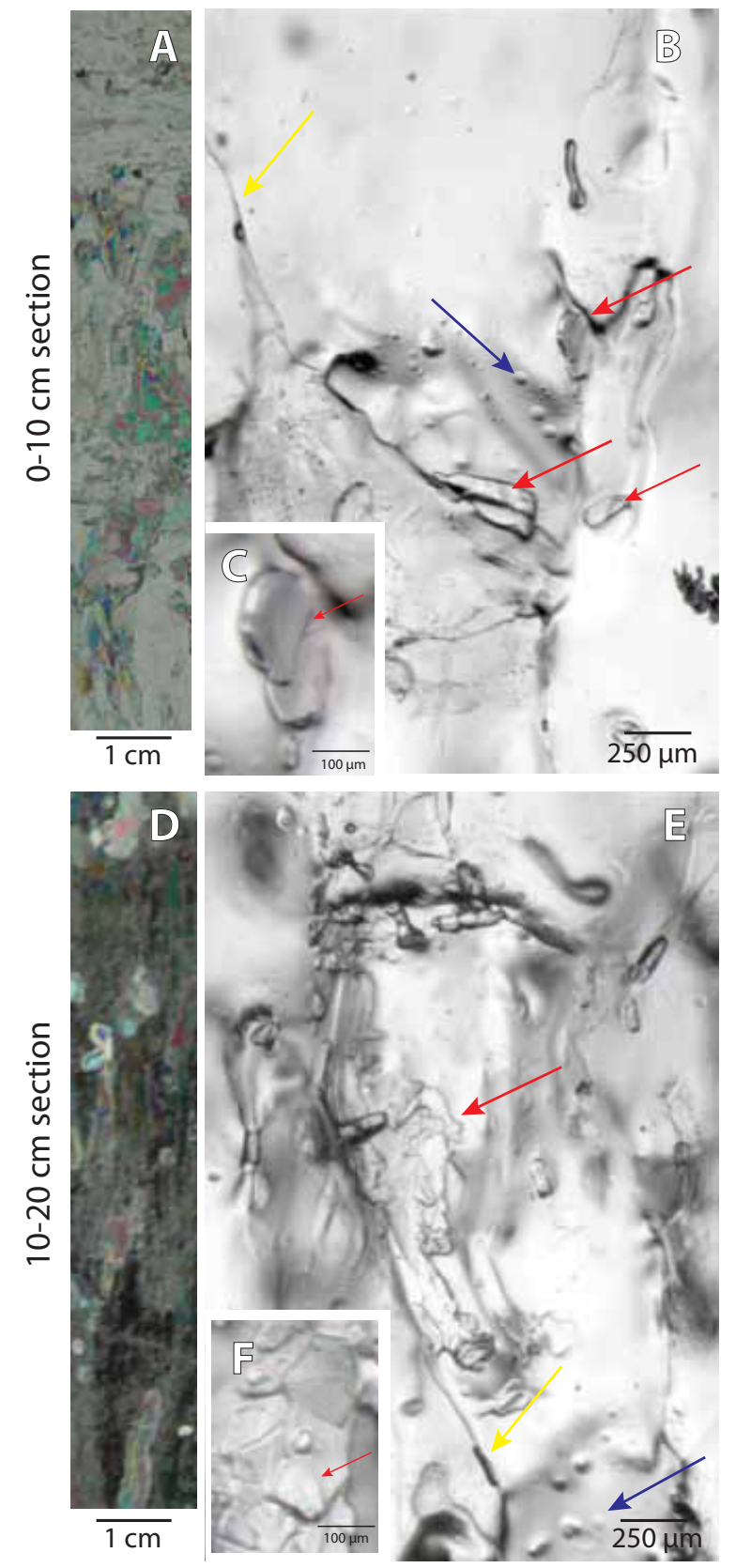

Fig. 4. Images of sea ice with ikaite crystals, from POLY I. (A, D) Sea ice texture (polarized light); (B, E) microscopic image of sea ice. Yellow arrows point to ice crystal boarders, blue arrows to brine pockets, and red arrows to ikaite crystals. $(\mathbf{C}, \mathbf{F})$ Ikaite crystals at higher magnification. (A), (B) and (C) from 0-10 cm section; (D), (E) and (F) from 10-20 cm section.

morphology, and were easily recognized with two significant variations: the more common thicker rhombs (Fig. 7a) and rather rare thinner plates (Fig. 7b). Whereas ikaite crystals in intact sea ice sometimes were assembled in aggregates such as the ones illustrated in Fig. 4e and f, they consisted mostly of isolated rhombic forms and thin plates as observed under 

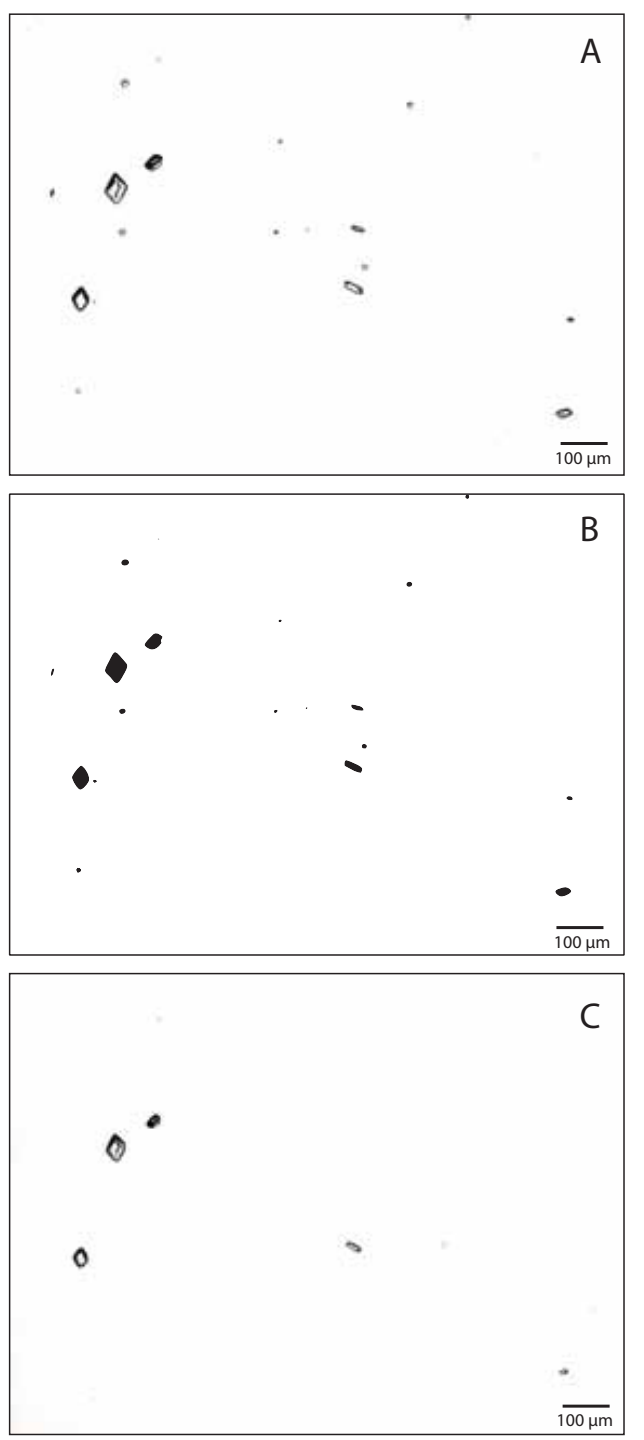

Fig. 5. Microscopic images of ikaite crystals (A) a few seconds after melting $50 \mathrm{mg}$ sea ice $(10-20 \mathrm{~cm}$ section) from POLY I. Image represents a very small fraction $(2 \mu \mathrm{g})$ of the sample. (B) Software (ImageJ $1.45 \mathrm{~s}$ ) processing of image A to find the number (19) and area $(0.48 \%$ of counting area) of the crystals. (C) Image taken after 2 min showing that crystals are dissolving.

the microscope immediately after ice platelets had melted (Fig. 5).

Surface TA concentrations of $600-800 \mu \mathrm{mol} \mathrm{kg}{ }^{-1}$ melted sea ice were measured at ICE I, with decreasing concentrations to $380 \mu \mathrm{mol} \mathrm{kg}{ }^{-1}$ melted sea ice in ice layers close to the water column (Fig. 8a). $T \mathrm{CO}_{2}$ values at ICE I had similar vertical distribution with lower concentrations. At POLY I site, TA values were measured at $\sim 800 \mu \mathrm{mol} \mathrm{kg}^{-1}$ melted sea ice near the surface, and decreased to $\sim 500 \mu \mathrm{mol} \mathrm{kg}^{-1}$ melted sea ice near the water column. As at ICE I, the vertical $T \mathrm{CO}_{2}$ concentrations at POLY I were similar to TA, but with lower values.
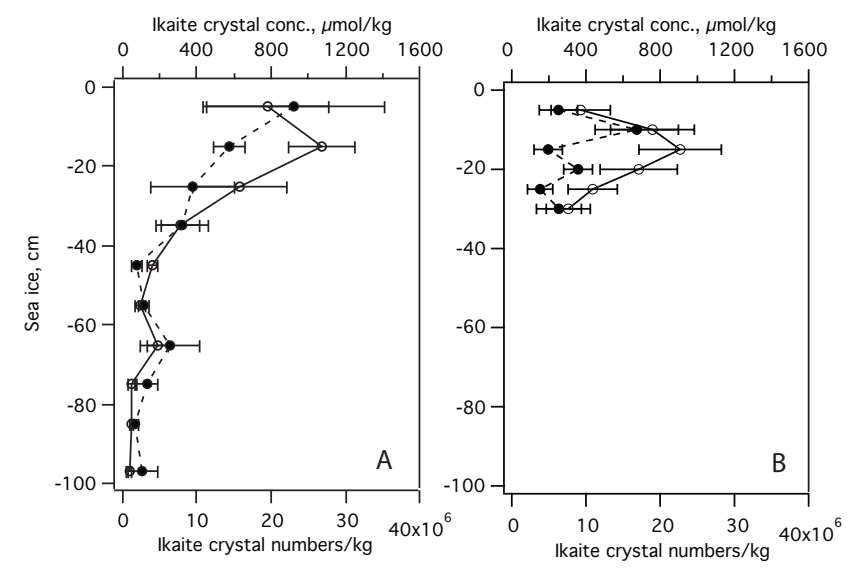

Fig. 6. Vertical distribution of ikaite crystals determined from image analysis. Abundance of crystals (-o-) and concentration of ikaite $(--\bullet-)$ at ICE I (A) and POLY I (B).

\section{Discussion}

\subsection{Spatial and temporal variability of ikaite occurrence and concentration}

Ikaite concentrations from this study are higher than those reported previously: 10 times higher than those measured in spring sea ice from Antarctica (Dieckmann et al., 2008), and 4 times higher than in surface summer ice from Fram Strait (160-240 $\mu \mathrm{mol} \mathrm{kg}{ }^{-1}$ melted sea ice; Rysgaard et al., 2012). The differences may be explained in part by differences in quantification procedure, as our study is unique in employing immediate analysis in the field without prolonged melting. The higher values we report may also reflect real differences between sites and seasons, as we present results for winter sea ice, while other studies were conducted in spring and summer with melt already apparent. As a result, a fraction of ikaite crystals in the previous studies may already have been dissolved due to ice warming and melting or lost via brine drainage. In addition, ikaite crystals were observed in the week-old POLY I sea ice and even within 1 hour in frost flowers and thin ice in an artificially opened lead (data to be presented elsewhere). This observation indicates dynamic conditions of ikaite formation even on short timescales. Understanding the dynamics of those processes is an important objective for future studies. Here, we note that higher concentrations of ikaite in surface sea ice are predicted by the FREZCHEM model (Marion et al., 2010). Assuming that a standard seawater $\left(S=35,\left[\mathrm{Na}^{+}\right]=0.4861\right.$, $\left[\mathrm{K}^{+}\right]=0.01058, \quad\left[\mathrm{Ca}^{2+}\right]=0.01065, \quad\left[\mathrm{Mg}^{2+}\right]=0.05475$, $\left[\mathrm{Cl}^{-}\right]=0.56664, \quad\left[\mathrm{SO}_{4}^{2-}\right]=0.02927, \quad\left[\mathrm{HCO}_{3}^{-}\right]=0.0023$; ions concentration unit: mole $\mathrm{kg}^{-1}$ water) freezes in an open system with $p \mathrm{CO}_{2}=320 \mu \mathrm{atm}$, the FREZCHEM model predicts an ikaite concentration of up to $620 \mu \mathrm{mol} \mathrm{kg}{ }^{-1}$ sea ice in the cold surface layer of ICE I, decreasing exponentially downwards (Fig. 9). Both the concentration range 
Table 1. X-ray diffraction data. Refined unit-cell parameters for ikaite crystals identified by $\mathrm{x}$-ray diffraction analysis. ( ) = Standard deviation, $\mathrm{R}=$ rhombs, $\mathrm{TP}=$ thin plate.

\begin{tabular}{|c|c|c|c|c|c|c|}
\hline \multicolumn{7}{|l|}{$\begin{array}{l}\text { ICE I } \\
\text { Section }\end{array}$} \\
\hline $\mathrm{cm}$ & & $a(\AA)$ & $b(\AA)$ & $c(\AA)$ & $\beta\left({ }^{\circ}\right)$ & $V\left(\AA^{3}\right)$ \\
\hline $0-10$ & $\mathrm{R}$ & $8.808(2)$ & $8.313(2)$ & $11.031(2)$ & $110.59(1)$ & $756.1(8)$ \\
\hline $10-20$ & $\mathrm{R}$ & $8.820(2)$ & $8.330(2)$ & $11.050(3)$ & $110.57(2)$ & 761.7(4) \\
\hline $20-30$ & $\mathrm{TP}$ & $8.823(3)$ & $8.326(3)$ & $11.049(4)$ & $110.64(2)$ & $759.6(7)$ \\
\hline $30-40$ & $\mathrm{R}$ & $8.813(2)$ & $8.312(2)$ & 11.034(3) & $110.60(1)$ & 756.7(4) \\
\hline $40-50$ & $\mathrm{R}$ & $8.817(3)$ & $8.312(2)$ & $11.027(3)$ & $110.58(2)$ & 756.6(5) \\
\hline $50-60$ & $\mathrm{R}$ & $8.812(2)$ & $8.311(1)$ & $11.040(2)$ & $110.58(1)$ & $756.9(6)$ \\
\hline $60-70$ & $\mathrm{R}$ & $8.831(3)$ & $8.320(2)$ & $11.047(3)$ & $110.55(2)$ & $760.1(6)$ \\
\hline $70-80$ & $\mathrm{R}$ & $8.812(2)$ & $8.318(2)$ & $11.031(3)$ & $110.56(2)$ & $757.0(8)$ \\
\hline $80-90$ & $\mathrm{R}$ & $8.819(2)$ & $8.315(2)$ & $11.025(3)$ & $110.57(2)$ & 758.3(5) \\
\hline $90-100$ & TP & $8.820(2)$ & $8.323(2)$ & $11.049(2)$ & $110.64(1)$ & $759.2(5)$ \\
\hline \multicolumn{7}{|l|}{$\begin{array}{l}\text { POLY I } \\
\text { Section }\end{array}$} \\
\hline $\mathrm{cm}$ & & $a(\AA)$ & $b(\AA)$ & $c(\AA)$ & $\beta\left(^{\circ}\right)$ & $V\left(\AA^{3}\right)$ \\
\hline $0-10$ & TP & $8.816(3)$ & $8.333(2)$ & $11.043(3)$ & $110.68(2)$ & 759.1(6) \\
\hline $10-20$ & $\mathrm{TP}$ & $8.810(1)$ & $8.320(1)$ & $11.033(1)$ & $110.58(1)$ & 757.1(2) \\
\hline
\end{tabular}

and distribution pattern agreed well with the empirical data at ICE I. Although the FREZCHEM modeling assumes that the system reaches thermodynamic equilibrium and is always open to a constant $p \mathrm{CO}_{2}$, assumptions that are not fulfilled under natural conditions, the modeling results nevertheless support the observation that ikaite concentration increases with decreasing temperature. Seasonally variable ikaite concentration, with highest values in winter, is thus expected.

It is a key point as to exactly where the crystals are located. If they are in the brine channels then they can potentially move with the circulation of brine as the temperatures change internally in the ice. If they are isolated from larger brine networks and are located at the interstices then they may remain trapped in the ice as convection occurs. This will make a big difference on the exchange through winter and well into spring. Our images document that ikaite crystals are located between the interstices of the sea ice matrix between the pure ice platelets. As they are particles they can be trapped between the small interstitial pore spaces and therefore retained in the ice. In contrast, solutes and gases $\left(\mathrm{CO}_{2}\right)$, as well as organic particles including microorganisms (Junge et al., 2001; Krembs et al., 2011), can be transported within the brine system. It was possible to see brine motion in the microscope as small particles and air bubbles moved between the interstices of ice platelets. Increasing the temperature by a few degrees significantly accelerated the transport velocity. The TA: bulk salinity ratio in sea ice was $84 \pm 4$ (ICE I) and $78 \pm 0.8$ (POLY I) as compared with the water column $67 \pm 3$ (ICE I) and $61 \pm 0.2$ (POLY I). Thus, the higher TA-S ratio in sea ice than in seawater shows that $\mathrm{CaCO}_{3}$ release adds a

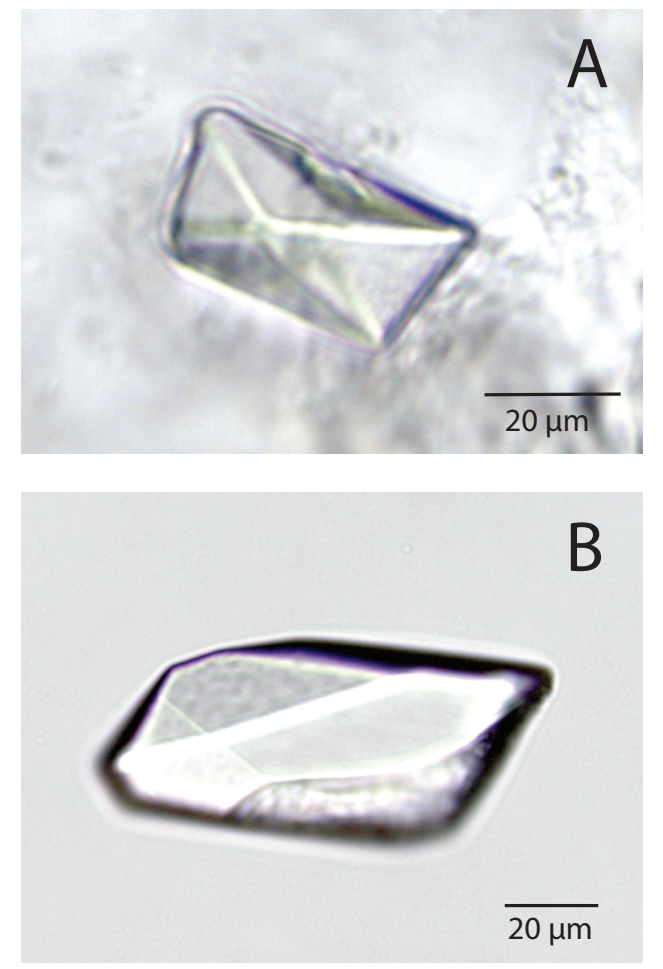

Fig. 7. Two most common forms of ikaite in freezing sea ice. (A) rhombs, (B) thin plates.
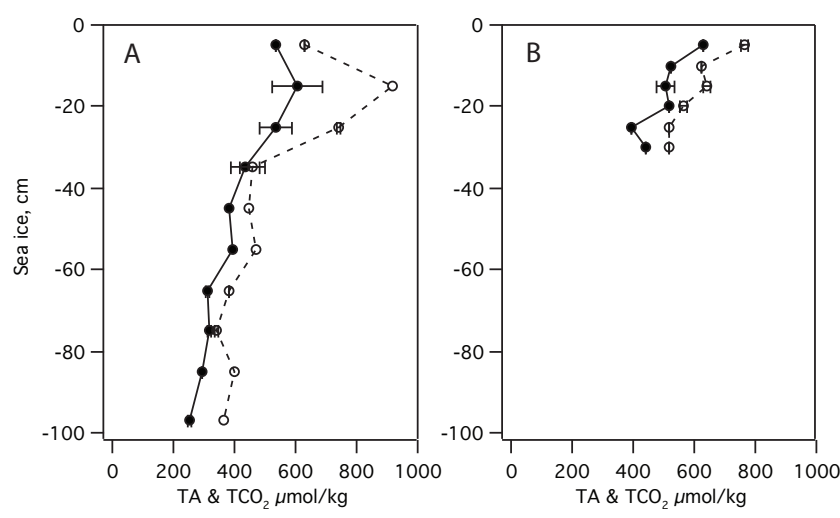

Fig. 8. Vertical profiles of concentration of total alkalinity (- -o- -) and dissolved inorganic carbon (-๑) in (A) at ICE I and (B) at POLY I.

further alkalinity contribution to the simple melt of ice. These observations confirm previous hypotheses (Rysgaard et al., $2007,2009,2011)$ that ikaite crystals are trapped within the sea ice matrix, whereas $\mathrm{CO}_{2}$ released through ikaite production (Eq. 1) and dissolved within the brine can be lost from the sea ice. As a result, $\mathrm{CaCO}_{3}$ stores twice as much TA as $T \mathrm{CO}_{2}$, hence TA of the meltwater increases relative to $T \mathrm{CO}_{2}$ in sea ice. When ikaite crystals dissolve during sea ice melt, surface water $p \mathrm{CO}_{2}$ will decrease. This is important as low 


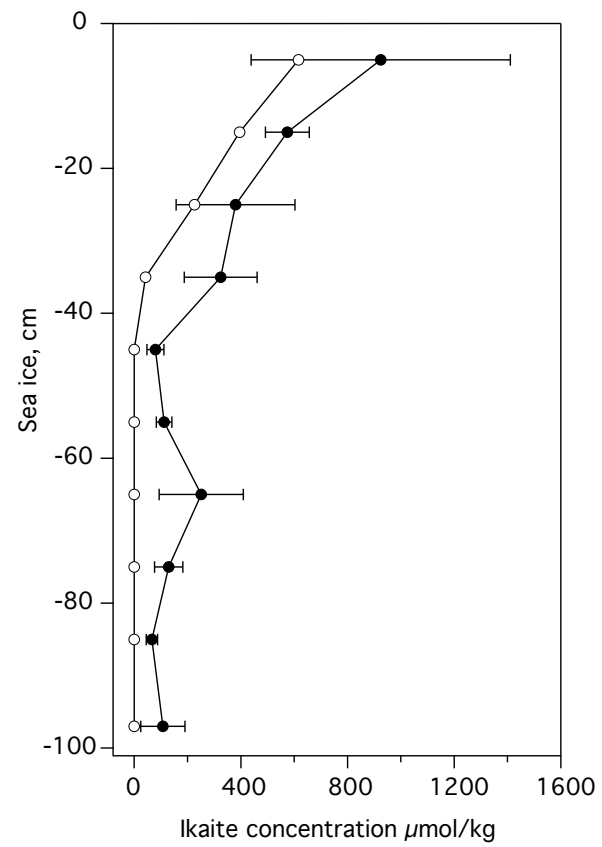

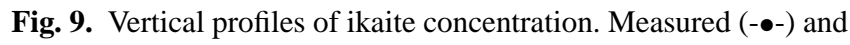
FREZCHEM calculated (-o-) at ICE I.

$p \mathrm{CO}_{2}$ values in surface waters will lead to a large $\mathrm{CO}_{2}$ flux from the atmosphere into the ocean.

Bulk TA concentrations in surface ice layers (including ikaite crystals) were within the same range as ikaite concentrations, implying that most of TA is present in the crystal form of ikaite and, thus, trapped within the surface sea ice matrix. In contrast, bulk TA concentrations were higher than ikaite crystal concentrations in the internal and bottom layer of the sea ice at both stations, implying that not all TA in the lower ice layers originate from ikaite crystals. One explanation for this finding invokes dissolution or reduced growth rate of ikaite in interior ice layers due to exposure to excess $\mathrm{CO}_{2}$ originating from cold upper ice layers, where elevated brine concentrations of $\mathrm{Ca}^{2+}$ and $\mathrm{HCO}_{3}^{-}$are higher due to lower brine volumes. The $\mathrm{CO}_{2}$ released in upper ice could be transported to interior ice layers by downward brine drainage. Low $\mathrm{pH}$ conditions in interior ice layers have recently been reported for experimental sea ice (Hare et al., 2013). Here, vertical $\mathrm{pH}$ profiles for bulk ice, as measured at near-freezing temperatures, revealed a consistent $\mathrm{C}$-shaped pattern during columnar ice growth, with the highest $\mathrm{pH}$ values ( $>9)$ in both the exterior (top and bottom) ice sections and lowest $\mathrm{pH}(\sim 7)$ in the interior ice sections (Hare et al., 2013). Calculating the vertical $\mathrm{pH}$ profile at ICE I, using temperature and bulk salinity (Fig. 2 ) and TA and $T \mathrm{CO}_{2}$ conditions (Fig. 8) from our winter ice study, yielded a similar C-shaped $\mathrm{pH}$ profile with high $\mathrm{pH}(>9)$ in surface and bottom ice layers, and lower $\mathrm{pH}(\sim 8)$ in interior layers. At POLY I, a C-shaped $\mathrm{pH}$ profile was also estimated, although the $\mathrm{pH}$ values in exterior layers were slightly lower $(\sim 8.5)$. The sum of these findings suggests that downward transport of $\mathrm{pH}$ equivalents could be responsible for dissolving ikaite in the interior ice layers.

Another mechanism that could affect the dissolution/precipitation dynamics of trapped ikaite crystals involves convective solutes (Worster and Wettlaufer, 1997) ensuring contact between the interior brine system and the underlying water column. $\mathrm{CO}_{2}$-enriched brine can exchange with seawater via gravity drainage (Notz and Worster, 2009) if the brine volume is above $5 \%$ to allow vertical ice permeability (Cox and Weeks, 1975; Notz and Worster, 2009). In this study, brine volume fractions were above $5 \%$ in the lower $50 \mathrm{~cm}$ of sea ice at ICE I, and throughout the ice column at POLY I. Thus, the increase in $\mathrm{pH}$ in the sea ice layers close to the water column could be caused by replenishment of brine with surface seawater ( $\mathrm{pH} 8.1-8.3$ ).

\subsection{Role of ikaite in seawater $\mathrm{CO}_{2}$ system and gas exchange}

The observation that ikaite crystals are trapped within the sea ice matrix, while $\mathrm{CO}_{2}$ dissolved in the brine through ikaite production (Eq. 1) can be mobile (lost from the ice with brine), means that ikaite crystal formation increases the amount of $\mathrm{CO}_{2}$ available for export beyond that attributed solely to the solubility effect. The implication is that, in an open system, TA is preferentially stored in the sea ice as ikaite, raising the buffering capacity of sea ice (and surface water) upon melting and subsequent crystal dissolution. With trapped ikaite crystals, ice melt will therefore lead to both lower surface water salinity and $p \mathrm{CO}_{2}$. As the low $p \mathrm{CO}_{2}$ meltwater remains at the ocean surface due to density stratification gradient, $\mathrm{CO}_{2}$ flux from the atmosphere to the surface will be enhanced (Rysgaard et al., 2012). Based on data from this study, the melting of sea ice (salinity from Fig. 2, TA and $\mathrm{TCO}_{2}$ from Fig. 8) at $0^{\circ} \mathrm{C}$ and dissolution of observed concentrations of ikaite (Fig. 6) would result in meltwater with a $p \mathrm{CO}_{2}$ of $<15 \mu \mathrm{atm}$ at both sites. This value is far below atmospheric values of $390 \mu \mathrm{atm}$ and surface water concentrations of $315 \mu \mathrm{atm}$ measured in this study. Hence, the meltwater can increase the air-sea $\mathrm{CO}_{2}$ uptake.

During ice growth, $p \mathrm{CO}_{2}$ in the brine system will increase and reduce $\mathrm{pH}$ in interior ice layers. In the surface ice layer, released $\mathrm{CO}_{2}$ may escape to the atmosphere or be transported to deeper ice layers by downward brine drainage. Few measurements of air-sea $\mathrm{CO}_{2}$ fluxes have been reported for winter conditions. Geilfus et al. (2012) detected no $\mathrm{CO}_{2}$ release for ice surface temperatures below $-10^{\circ} \mathrm{C}$, instead observing a small negative flux (into the sea ice) of $0.23 \mathrm{mmol} \mathrm{m}^{-2} \mathrm{~d}^{-1}$ over sea ice in the Amundsen Gulf, Beaufort Sea. Miller et al. (2011) measured fluctuating $\mathrm{CO}_{2}$ fluxes over sea ice with strong downward fluxes in February in the Southern Beaufort Sea. Sejr et al. (2011) observed that $99 \%$ of $\mathrm{TCO}_{2}$ in newly forming ice over drilled holes 
in meter thick sea ice was rejected to the underlying seawater in Young Sound, Greenland. The suggestion that most of the $\mathrm{CO}_{2}$ released through ikaite crystal formation will sink towards the seawater in dense brine is consistent with these several findings.

The fate of $\mathrm{CO}_{2}$ expelled from the sea ice to seawater remains unclear. Dense brine production in the polynya region (Anderson et al., 2004) may provide a mechanism to deliver $\mathrm{CO}_{2}$ below the mixed layer, making ikaite production in sea ice a "carbon pump" that removes $\mathrm{CO}_{2}$ from the surface ocean to deeper water layers (Rysgaard et al., 2009, 2011). Low-density ice meltwater remaining at the surface will facilitate atmospheric $\mathrm{CO}_{2}$ deposition as a result of ikaite dissolution. An air-sea $\mathrm{CO}_{2}$ flux of $-10.6 \mathrm{mmol} \mathrm{m}^{-2} \mathrm{~d}^{-1}$ has been reported during spring and summer for the region previously (Rysgaard et al., 2012).

Geilfus et al. (2012) calculated, based on the carbon chemistry in the sea ice brine in equilibrium partitioning with the atmosphere, that melting of a $1.3 \mathrm{~m}$ thick sea ice cover within one month in the Beaufort Sea could lead to $\mathrm{CO}_{2}$ fluxes ranging from -1.2 to $-3.1 \mathrm{mmol} \mathrm{m}^{-2} \mathrm{~d}^{-1}$, which are comparable to $\mathrm{CO}_{2}$ fluxes measured over melt ponds. At ICE I, we calculated the potential influence of melting the entire ice cover into a $20 \mathrm{~m}$ thick mixed layer (typical for summer conditions at this location) on the $\mathrm{CO}_{2}$ flux in the region, using the measured ice carbon chemistry (salinity of 6.5 , TA of $516 \mu \mathrm{mol} \mathrm{kg}{ }^{-1}, T \mathrm{CO}_{2}$ of $406 \mu \mathrm{mol} \mathrm{kg}^{-1}$, and average temperature of $0^{\circ} \mathrm{C}$ ) and the initial mixed layer characteristics (average temperature of $0^{\circ} \mathrm{C}$, salinity of 31.7 , TA of $2276 \mu \mathrm{mol} \mathrm{kg}^{-1}$, and $T \mathrm{CO}_{2}$ of $\left.2101 \mu \mathrm{mol} \mathrm{kg}^{-1}\right)$. The resultant conditions in a $20 \mathrm{~m}$ mixed layer (temperature of $0^{\circ} \mathrm{C}$, salinity of 30.4 , TA of $2184 \mu \mathrm{mol} \mathrm{kg}{ }^{-1}$, and $T \mathrm{CO}_{2}$ of $2013 \mu \mathrm{mol} \mathrm{kg}^{-1}$ ) would cause a $14 \mu \mathrm{atm}$ decrease in $p \mathrm{CO}_{2}$. Assuming the melt occurs over one month, the resultant air-sea $\mathrm{CO}_{2}$ flux to return to pre-melt conditions would be $-5.9 \mathrm{mmol} \mathrm{m}^{-2} \mathrm{~d}^{-1}$, which falls within the range reported previously.

This calculation is based on a single melt event and does not account for the numerous cycles of sea ice growth and melt characteristic of polynya systems (Tamura and Ohshima, 2011; Drucker et al., 2011). The polynya formation at POLY I is predominantly governed by mechanical forcing caused by northerly gales; it has been classified as a winddriven shelf water system (Pedersen et al., 2010), where sea ice formation is continuous and rejection of $\mathrm{CO}_{2}$ to deeper water layer with dense brine occurs (Anderson et al., 2004). Ikaite crystals trapped in the forming sea ice will be exported with the ice to melt elsewhere. Such polynya systems are thus likely to export $\mathrm{CO}_{2}$ to depth effectively. Based on results presented here, enhanced ice production in winter polynyas would add considerable amounts of TA to the surface waters in the form of ikaite crystals from sea ice, lowering surface water $p \mathrm{CO}_{2}$ upon ice melt and crystal dissolution, and increasing the potential for seawater uptake of $\mathrm{CO}_{2}$.
An interesting observation in the polynya region we have studied (Sejr et al., 2011; Papakyriakou et al., 2013) is that the $p \mathrm{CO}_{2}$ levels in the water column are very low, gradually increasing with depth from surface values of $315 \mu \mathrm{atm}$ to $360 \mu$ atm at $80 \mathrm{~m}$. During the present study, the average $p \mathrm{CO}_{2}$ concentration of the upper $20 \mathrm{~m}$ water column was $335 \mu \mathrm{atm}$ compared to $390 \mu \mathrm{atm}$ in the atmosphere. As melting $1 \mathrm{~m}$ of sea ice will reduce $p \mathrm{CO}_{2}$ levels by $14 \mu \mathrm{atm}$ in a $20 \mathrm{~m}$ water column according to the calculations above, $\sim 4 \mathrm{~m}$ of sea ice would need to melt locally to explain the low $p \mathrm{CO}_{2}$ concentrations in the water column. In polynya areas the sea ice production is usually much greater than indicated by the annual sea ice thickness due to the continued production of ice (McLaren, 2006). The local ice production at POLY I is thus likely responsible for much more larger ice growth than the April-May ice thickness of 1.4$1.6 \mathrm{~m}$ usually observed at ICE I (Rysgaard and Glud, 2007). Furthermore, the study site is located on the NE Greenland Sea shelf where large amounts of sea ice exported from the Arctic Ocean through Fram Strait subsequently melt during southward transport toward the Denmark Strait (Vinje, 2001). Sea ice containing ikaite crystals as observed in the present study may well explain a large part of the low $p \mathrm{CO}_{2}$ levels in the upper part of the water column due to melting of sea ice from previous summer/autumn in the area. Biological $\mathrm{CO}_{2}$ fixation will also contribute to the atmospheric drawdown, but constraining this factor is beyond the scope of the present study. The current work nevertheless supports previous model calculations from the area estimating that melting of sea ice exported from the Arctic Ocean into the East Greenland current and the Nordic Seas greatly increases the seasonal and regional $\mathrm{CO}_{2}$ uptake in the area (Rysgaard et al., 2009). More work is required to determine how applicable our results are to other regions of the Arctic (or Antarctic), given the variable nature of $\mathrm{CaCO}_{3}$ among the few available ikaite studies (above references) and the seasonal nature of $p \mathrm{CO}_{2}$ in ice-free Arctic systems (Mucci et al., 2010; Cai et al., 2010).

\section{Conclusions}

We report unique observations of ikaite in unmelted ice and vertical profiles of ikaite abundance and concentration in sea ice for the crucial season of winter. Ikaite crystals, ranging in size from a few $\mu \mathrm{m}$ to $700 \mu \mathrm{m}$, were observed to concentrate in the interstices between the ice platelets in both granular and columnar sea ice. Their concentration decreased with depth from surface-ice values of $700-900 \mu \mathrm{mol} \mathrm{kg}^{-1}$ ice $\left(\sim 25 \times 10^{6}\right.$ crystals kg$\left.{ }^{-1}\right)$ to values of $100-200 \mu \mathrm{mol} \mathrm{kg}{ }^{-1}$ ice $\left(1-7 \times 10^{6} \mathrm{crystals} \mathrm{kg}^{-1}\right)$ near the ice-water interface, all of which are much higher (4-10 times) than those reported in the few previous studies. Direct measurements of TA in surface layers fell within the same range as ikaite concentration, whereas TA concentrations in 
interior and bottom layers were twice as high. This depthrelated discrepancy suggests interior ice processes where ikaite crystals form in surface sea ice layers and partly dissolve in internal ice layers. The result is a $\mathrm{C}$-shaped $\mathrm{pH}$ profile with high $\mathrm{pH}(>9)$ in surface and bottom ice layers, and lower $\mathrm{pH}(\sim 8)$ in interior layers. Based on results presented here, enhanced ice production in winter polynyas would add considerable amounts of TA to the surface waters in the form of ikaite crystals from sea ice, lowering surface water $p \mathrm{CO}_{2}$ upon ice melt and crystal dissolution, and increasing the potential for seawater uptake of $\mathrm{CO}_{2}$ in regions downstream where the ice melts.

Acknowledgements. The study received financial support from Canada Excellence Research Chair (CERC) program, the Danish Agency for Science, Technology and Innovation, the Arctic Research Centre at Aarhus University, the Commission for Scientific Research in Greenland. J. W. D. acknowledges support from OPP RAPID award from the US National Science Foundation. Egon Frandsen, Ivali Lennert and Bruce Johnson are thanked for outstanding assistance in the field.

Edited by: R. Lindsay

\section{References}

Anderson, L. G., Falck, E., Jones, E. P., Jutterström, S., and Swift, J. $\mathrm{H}$.: Enhanced uptake of atmospheric $\mathrm{CO}_{2}$ during freezing of seawater: A field study in Storfjorden, Svalbard, J. Geophys. Res., 109, C06004, doi:10.1029/2003JC002120, 2004.

Assur, A.: Composition of sea ice and its tensile strength, SIPRE Research Report 44, 1960.

Cai, W.-J., Chen, L., Chen, B., Gao, Z., Lee, S. H., Chen, J., Pierrot, D., Sullivan, K., Wang, Y., Hu, X., Huang, W.-J., Zhang, Y., Xu, S., Murata, A., Grebmeier, J. M., Jones, E. P., and Zhang, H.: Decrease in the $\mathrm{CO}_{2}$ Uptake Capacity in an Ice-Free Arctic Ocean Basin, Science, 329, 556-559, doi:10.1126/science.1189338, 2010.

Cox, G. F. N. and Weeks, W. F.: Brine drainage and initial salt entrapment in sodium chloride ice, CRREL Res. Rep. 345, US Army Cold Reg. Res. and Eng. Lab., Hanover, N.H., 1975.

Cox, G. F. N. and Weeks, W. F.: Equations for determining the gas and brine volumes in sea ice samples, J. Glaciol., 29, 306-316, 1983.

Delille, B., Jourdain, B., Borges, A. V., Tison, J.-P., and Delille, D.: Biogas $\left(\mathrm{CO}_{2}, \mathrm{O}_{2}\right.$, dimethylsulfide $)$ dynamics in spring Antarctic fast ice, Limnol. Oceanogr., 52, 1367-1379, doi:10.4319/lo.2007.52.4.1367, 2007.

Dickson, A. G. and Millero, F. J.: A comparison of the equilibrium constants for the dissociation of carbonic acid in seawater media, Deep-Sea Res., 34, 1733-1743, 1987.

Dickson, A. G. and Millero, F. J.: Corrigenda, Deep-Sea Res., 36, p. $983,1989$.

Dieckmann, G. S., Nehrke, G., Papadimitriou, S., Göttlicher, J., Steininger, R., Kennedy, H., Wolf-Gladrow, D., and Thomas, S. N.: Calcium carbonate as ikaite crystals in Antarctic sea ice, Geophys. Res. Lett., 35, L08501, doi:10.1029/2008GL033540, 2008.
Dieckmann, G. S., Nehrke, G., Uhlig, C., Göttlicher, J., Gerland, S., Granskog, M. A., and Thomas, D. N.: Brief Communication: Ikaite $\left(\mathrm{CaCO}_{3} \cdot 6 \mathrm{H}_{2} \mathrm{O}\right)$ discovered in Arctic sea ice, The Cryosphere, 4, 227-230, doi:10.5194/tc-4-227-2010, 2010.

Drucker, R., Martin, S., and Kwok, R.: Sea ice production and export from coastal polynyas in the Weddell and Ross Seas, Geophys. Res. Lett., 38, L17502, doi:10.1029/2011GL048668, 2011.

Ehn, J. K., Hwang, B. J., Galley, R., and Barber D. G.: Investigations of newly formed sea ice in the Cape Bathurst polynya: 1. Structural, physical, and optical properties, J. Geophys. Res., 112, C05002, doi:10.1029/2006JC003702, 2007.

Geilfus, N.-X., Carnat, G., Papakyriakou, T., Tison, J.-L., Else, B., Thomas, H., Shadwick, E., and Delille, B.: Dynamics of $\mathrm{pCO}_{2}$ and related air-sea $\mathrm{CO}_{2}$ fluxes in the Arctic coastal zone (Amundsen Gulf, Beaufort Sea), J. Geophys. Res., 117, C00G10, doi:10.1029/2011JC007118, 2012.

Geilfus, N.-X., Carmat, G. Dieckman, G. S., Halden, N., Nehrke, G., Papakyriakou, T., Tison, J.-L., and Delille, B.: First estimates of the contribution of $\mathrm{CaCO}_{3}$ precipitation to the release of $\mathrm{CO}_{2}$ to the atmosphere during young sea ice growth. J. Geophys. Res. Ocean, 118, 1-12, doi:10.1029/2012JC007980, 2013.

Golden, K. M., Ackley, S. F., and Lytle, V. I.: The percolation phase transition in sea ice, Science, 282, 2238-2241, 1998.

Golden, K. M., Eicken, H., Heaton, A. L., Miner, J., Pringle, D. J., and Zhu, J.: Thermal evolution of permeability and microstructure in sea ice, Geophys. Res. Lett. 34, L16501, doi:10.1029/2007GL030447, 2007.

Hansen, J. W., Thamdrup, B., and Jørgensen, B. B.: Anoxic incubation of sediment in gas tight plastic bags: A method for biogeochemical process studies, Mar. Ecol. Prog. Ser., 208, 273-282, 2000.

Haraldsson, C., Anderson, L. G., Hasselöv, M., Hult, S., and Olsson, K.: Rapid, high-precision potentiometric titration of alkalinity in ocean and sediment pore water, Deep-Sea Res. Pt. I, 44, 20312044, 1997.

Hare, A. A., Wang, F., Barber, D., Geilfus, N.-X., Galley, R., and Rysgaard, S.: pH evolution in sea ice grown at an outdoor experimental facility, Mar. Chem., in press, 2013.

Hesse, K. F. and Küppers, H.: Refinement of the structure of Ikaite, $\mathrm{CaCO}_{3} \bullet 6 \mathrm{H}_{2} \mathrm{O}, \mathrm{Z}$. Krystallographie, 163, 227-231, 1983.

Johnson, K. M., Sieburth, J. M., Williams, P. J., and Brändström, L.: Coulometric total carbon dioxide analysis for marine studies: Automation and calibration, Mar. Chem., 21, 117-133, 1987.

Junge, K., Krembs, C., Deming, J., Stierle, A., and Eicken, H.: A microscopic approach to investigate bacteria under in situ conditions in sea-ice samples. Ann. Glaciol., 33, 304-310, 2001.

Krembs, C., Eicken, H., and Deming, J. W.: Exopolymer alteration of physical properties of sea ice and implications for ice habitability and biogeochemistry in a warmer Arctic, Proc. Natl. Acad. Sci., USA, 108, 3653-3658, 2011.

Leppäranta, M. and Manninen, T.: The brine and gas content of sea ice with attention to low salinities and high temperatures, Finnish Institute of Marine Research Internal Report, Helsinki, Finland, 15 pp., 1988.

Lewis, E. and Wallace D.: The program CO2SYS.EXE can be downloaded at: http://cdiac.esd.ornl.gov/oceans/co2rprtnbk.html (last access: 24 September 2012), 2012.

Marion, G. M., Farren, R. E., and Komrowski, A. J.: Alternative pathways for seawater freezing, Cold Reg. Sci. Technol., 29, 
259-266, 1999.

Marion, G. M., Mironenko, M. V., and Roberts, M. W.: FREZCHEM: A geochemical model for cold aqueous solutions, Comput. Geosci., 36, 10-15, 2010.

McLaren, A. J., Banks, H. T., Durman, C. F., Gregory, J. M., Johns, T. C., Keen, A. B., Ridley, J. K., Roberts, M. J., Lipscomb, W. H., Connolley, W. M., and Laxon, S. W.: Evaluation of the sea ice simulation in a new coupled atmospheric-ocean climate model (HadGEM1), J. Geophys. Res., 111, C12014, doi:10.1029/2005JC003033, 2006.

Mehrbach, C., Culberson, H., Hawley, J. E., and Pytkowicz, R. M.: Measurement of the apparent dissociation constants of carbonic acid in seawater at atmospheric pressure, Limnol. Oceanogr., 18, 897-907, 1973.

Miller, L. A., Papakyriakou, T. N. Collins, R. E., Deming, J. W., Ehn, J., Macdonald, R. W., Mucci, A., Owens, O., Raudsepp, M., and Sutherland, N.: Carbon dynamics in sea ice: A winter flux time series, J. Geophys. Res., 116, C02028, doi:10.1029/2009JC006058, 2011.

Mucci, A., B. Lansard, L. A. Miller, and Papakyriakou, T. N.: $\mathrm{CO}_{2}$ fluxes across the air-sea interface in the southeastern Beaufort Sea: Ice-free period, J. Geophys. Res., 115, C04003, doi:10.1029/2009JC005330, 2010.

Nedashkovsky, A. P., Khvedynich, S. V., and Petovsky, T. V.: Alkalinity of sea ice in the high-latitudinal arctic according to the surveys performed at north pole drifting station 34 and characterization of the role of the arctic in the $\mathrm{CO}_{2}$ exchange, Oceanology, 49, 55-63, doi:10.1134/s000143700901007x, 2009.

Notz, D. and Worster, M. G.: Desalination processes of sea ice revisited, J. Geophys. Res., 114, C05006, doi:10.1029/2008JC004885, 2009.

Papadimitriou, S., Kennedy, H., Norman, L., Kennedy, D. P., Dieckmann, G. S., and Thomas, D. T.: The effect of biological activity, $\mathrm{CaCO}_{3}$ mineral dynamics, and $\mathrm{CO}_{2}$ degassing in the inorganic carbon cycle in sea ice in late winter-early spring in the Weddell Sea, Antarctica, J. Geophys. Res., 117, C08011, doi:10.1029/2012JC008058, 2012.

Papakyriakou, T. N., Rysgaard, S., Geilfus, N. X., Pucko, M., Glud, R. N., Sejr, M. K., and Barber, D.: Seasonal variation in the carbon budget of a sea-ice dominated fjord system: Young Sound, Greenland, in preparation, 2013.

Pedersen, J. T. P., Kaufmann, L. H., Kroon, A., and Jakobsen, B. H.: The northeast Greenland Sirius Water Polynya dynamics and variability inferred from satellite imagery, Geogr. Tidsskr., 110, 131-142, 2010.
Rysgaard, S. and Glud, R. N.: Carbon cycling in Arctic marine ecosystems: Case study - Young Sound, Medd Greenland, Bioscience, 58, 216 pp., 2007.

Rysgaard, S., Glud, R. N., Sejr, M. K., Bendtsen, J., and Christensen, P. B.: Inorganic carbon transport during sea ice growth and decay: a carbon pump in polar seas, J. Geophys. Res., 112, C03016, doi:10.1029/2006JC003572, 2007.

Rysgaard, S., Glud, R. N., Sejr, M. K., Blicher, M. E., and Stahl, H. J.: Denitrification activity and oxygen dynamics in Arctic sea ice, Polar Biol., 31, 527-537, 2008.

Rysgaard, S., Bendtsen, J. B., Pedersen, L. T., Ramløv, H., and Glud, R. N.: Increased $\mathrm{CO}_{2}$ uptake due to sea-ice growth and decay in the Nordic Seas, J. Geophys. Res., 114, C09011, doi:10.1029/2008JC005088, 2009.

Rysgaard, S., Bendtsen, J., Delille, B., Dieckmann, G., Glud, R. N., Kennedy, H., Mortensen, J., Papadimitriou, S., Thomas, D., and Tison, J.-L.: Sea ice contribution to air-sea $\mathrm{CO}_{2}$ exchange in the Arctic and Southern Oceans, Tellus B, 63, 823-830, doi:10.1111/j.1600-0889.2011.00571.x, 2011.

Rysgaard, S., Glud, R. N., Lennert, K., Cooper, M., Halden, N., Leakey, R. J. G., Hawthorne, F. C., and Barber, D.: Ikaite crystals in melting sea ice - implications for $p \mathrm{CO}_{2}$ and $\mathrm{pH}$ levels in Arctic surface waters, The Cryosphere, 6, 901-908, doi:10.5194/tc6-901-2012, 2012.

Sejr, M. K., Krause-Jensen, D., Rysgaard, S., Sørensen, L. L., Christensen, P. B., and Glud, R. N.: Air-sea flux of $\mathrm{CO}_{2}$ in arctic coastal waters influenced by glacial melt water and sea ice, Tellus 63B, 815-822, doi:10.1111/j.1600-0889.2011.00540.x, 2011.

Tamura, T. and Ohshima, K. I.: Mapping of sea ice production in the Arctic coastal polynyas, J. Geophys. Res., 116, C07030, doi:10.1029/2010JC006586, 2011.

Unesco tech. papers in the marine science no. 28. Eight report. Joint panel on oceanographis tables and standards, Annex 6: Freezing point of seawater, edited by: Millero, F. J., 29-35, 1978.

Vinje, T.: Fram Strait ice fluxes and atmospheric circulation: 19502000, J. Climate, 14, 3508-3517, 2001.

Weeks, W. F. and Ackley, S. F.: The growth, structure and properties of sea ice, in: The Geophysics of Sea Ice, edited by: Untersteiner, N., Plenum, New York, 1986.

Worster, M. G. and Wettlaufer, J. S.: Natural convection, solute trapping, and channel formation during solidification of seawater, J. Phys. Chem. B, 101, 6132-6136, 1997. 